\title{
PENGEMBANGAN BUKU AJAR BIODIVERSITAS BERBASIS KAJIAN ETNOBIOLOGI SUKU DAYAK LOSARANG
}

\author{
Lesy Luzyawati, Lissa \\ Pendidikan Biologi, FKIP, Universitas Wiralodra \\ Email: lesy.luzyawati@unwir.ac.id
}

DOI: dx.doi.org/10.26418/jpmipa.v11i1.37598

\begin{abstract}
The textbooks used so far have not utilized learning resources to the fullest, such as the utilization of existing potential in the surrounding environment, planting values, and environmental awareness.Biodiversity textbook based on ethnobiology studies of the Suku Dayak Losarang is a product of the development of textbooks that can be used in biology learning on the concept of biodiversity.This study aims to look at the feasibility of biodiversity textbooks based on the ethnobiology study of the Suku Dayak Losarang Tribe and see the effectiveness of the textbook in biology learning in class X senior high school. This type of research is Research and Development $(R \& D)$ with eight stages of development models. Product Textbooks are validated by experts and practitioners using validation sheets. The validation results show that the book is suitable for use because it is good in terms of content worthiness, linguistics, and presentation. The textbook was tested on a small scale test and continued with a large scale test. The results of the effectiveness test using the different test showed that the biodiversity textbook based on the Suku Dayak Losarang was effectively used in biologylearning. Student responses to textbooks also scored high on all indicators.
\end{abstract}

Keywords: Biodiversity,Textbooks, Suku Dayak Losarang, Ethnobiology, Biology learning

\begin{abstract}
Abstrak
Buku ajar yang digunakan selama ini belum memanfaatkan sumber belajar secara maksimal, seperti pemanfaatan potensi yang ada di lingkungan sekitar, penanaman nilai, dan kesadaran lingkungan hidup. Buku ajar biodiversitas berbasis kajian etnobiologi Suku Dayak Losarang merupakan produk pengembangan buku ajar yang dapat digunakan dalam pembelajaran biologi pada konsep keanekaragaman hayati. Penelitian ini bertujuan untuk melihat kelayakan buku ajar biodiversitas berbasis kajian etnobiologi Suku Dayak Losarang dan melihat efektivitas buku ajar tersebut dalam pembelajaran
\end{abstract}


biologi di kelas X. Jenis penelitian ini ialah Research and Development (R\&D) dengan 10 tahapan model pengembangan. Produk Buku ajar divalidasi oleh para ahli dan praktisi dengan menggunakan lembar validasi. Hasil validasi menunjukkan buku layak digunakan karena sudah baik dalam hal kelayakan isi, kebahasaan, dan penyajian. Saran dari validator dijadikan acuan dalam merevisi buku ajar biodiversitas Suku Dayak Losarang. Buku ajar hasil revisi diujicobakan pada uji skala kecil (satu sekolah) dan dilanjutkan uji skala besar (tiga sekolah). Hasil uji efektivitas menggunakan uji t menunjukkan bahwa buku ajar biodiversitas berbasis Suku Dayak Losarang efektif digunakan dalam pembelajaran biologi. Respon siswa terhadap buku ajar juga mendapat nilai tinggi pada semua indikator. Artinya buku ajar biodiversitas berbasis kajian Suku Dayak Losarang dapat digunakan pada pembelajaran keanekaragaman hayati di kelas X SMA dan dapat disebarluaskan khususnya di Kabupaten Indramayu.

Kata kunci: Keanekaragaman hayati, Buku ajar, Suku Dayak Losarang, Etnobiologi, Pembelajaran Biologi

Tingginya biodiversitas di Indonesia secara perlahan semakin berkurang keberadaannya akibat dari perusakan terus-menerus, baik itu secara alami maupun disengaja. Berbeda dengan kerusakan secara alami, kerusakan yang disengaja dampaknya lebih buruk bagi lingkungan. Hal ini merupakan salah satu indikasi dari rendahnya tingkat pengetahuan masyarakat dan kurangnya kesadaran dalam mengelola biodiversitas. Salah satu faktor penyebabnya adalah pola pendidikan serta pembelajaran yang mengabaikan nilai-nilai yang dianut oleh masyarakat lokal yang penuh dengan nilai kearifan (Firdaus, 2017).

$$
\text { Pembelajaran biodiversitas }
$$

bertujuan untuk lebih mengenal keanekaragaman hayati khususnya daerah tempat dimana mendapatkan pendidikanyakni memperkenalkan potensi dan sumber daya yang berada didaerah lingkungan tempat terjadinya kegiatan belajar mengajar (Mardiansyah, et al., 2017). Pembelajaran biodiversitas di sekolah seharusnya melibatkan siswa secara aktif dan menggunakan lingkungan sekitar sebagai sumber belajar (Leksono, et al., 2015). Mulyasa (2013) menyatakan faktor yang menyebabkan rendahnya kualitas pembelajaran antara lain belum dimanfaatkannya sumber belajar baik oleh guru maupun siswa secara maksimal. Padahal karakteristik dari kurikulum 2013 berbasis kompetensi yaitu mendayagunakan keseluruhan sumber belajar.

Sumber belajar dapat berupa bahan ajar dalam bentuk buku ajar. Buku ajar merupakan salah satu buku yang menjadi acuan kegiatan belajar siswa. Buku ajar dapat membantu guru dalam menyampaikan materi pembelajaran sehingga tujuan pembelajaran tercapai (Tanjung \& Fahmi, 2015). Berdasarkan observasi dibeberapa Sekolah Menengah Atas (SMA) di Indramayu, buku ajar yang digunakan belum memanfaatkan sumber belajar secara maksimal, seperti pemanfaatan potensi yang ada di lingkungan sekitar, penanaman nilai, dan kesadaran lingkungan hidup. Pemanfaatan potensi lingkungan dapat dilakukan dalam pembelajaran biologi pada materi keanekaragaman hayati dengan menyisipkan nilai kearifan lokal 
didalamnya. Penelitian pengembangan buku ajar khususnya pada materi keanekaragaman hayati sudah dilakukan, diantaranya Utami (2017) pengembangan buku ilmiah populer keanekaragaman mangrove berbasis pembelajaran kontekstual pada materi keanekaragaman hayati di SMA. Bahri, et al. (2016) juga melakukan penelitian pengembangan modul keanekaragaman hayati dan virus berbasis model inkuiri terbimbing untuk siswa kelas X MAN 1 Malang. Bahan ajar tersebut masih berupa modul dan buku ilmiah populer. Penelitian mengenai pengembangan buku ajar telah dilakukan oleh Suwarni (2015) yang mengembangkan buku ajar berbasis lokal materi keanekaragaman laba-laba di Kota Metro. Namun demikian, belum terdapat buku ajar keanekaragaman hayati yang berbasis kajian etnobiologi.

Etnobiologi dalam penelitian ini terdiri atas etnobotani, etnozoologi, dan etnoekologi. Kajian etnobiologi bertujuan untuk menggali informasi dan kekayaan intelektual masyarakat lokal yang berkearifan lokal (Luzyawati \& Lissa, 2019). Masyarakat lokal di Kecamatan Losarang, Kabupaten Indramayu memiliki kearifan lokal tersendiri terhadap lingkungan hidup, mereka menamakan dirinya Suku Dayak Losarang. Etnobiologi Suku Dayak Losarang dengan melakukan pelestarian terhadap ekosistem di sekitarnya yang dilestarikan untuk kebutuhan sandang, pangan, pertanian, tempat tinggal, dan ritual. Etnozoologi Suku Dayak Losarang juga dengan tidak memanfaatkan spesies karena mereka memiliki prinsip "ngaji rasa" yang berarti tidak diizinkan untuk mengonsumsi atau memanfaatkan makhluk hidup (Luzyawati \& Lissa, 2019).

Hasil kajian etnobiologi Suku Dayak Losarang dikaitkan dalam pembelajaran biologi pada konsep keanekaragaman hayati dengan menyisipkan nilai-nilai kerifan lokal masyarakat tersebut yang dikemas dalam bentuk buku ajar. Penelitian ini bertujuan untuk melihat kelayakan buku ajar biodiversitas berbasis kajian etnobiologi Suku Dayak Losarang dan melihat efektivitas buku ajar tersebut dalam pembelajaran biologi kelas X SMA.

\section{METODE}

Penelitian ini termasuk ke dalam jenis penelitian Research \& Development (R\&D) yang mengacu pada Borg \& Gall (2003) yang diadaptasi sesuai dengan kebutuhan penelitian. Pengembangan dilakukan pada buku ajar biodiversitas berbasis kajian etnobiologi Suku Dayak Losarang Indramayu untuk siswa SMA. Tahapan pada model pengembangan ini yaitu: (1) Research and information collecting; (2) planning; (3) develop preliminary form of product; (4) preliminary field testing; (5) main product revision; (6) main field testing; (7) operational product revision; (8) operational field testing.

\section{(1) Research And Information Collecting}

Melakukan studi dokumen tentang materi keanekaragaman hayati tingkat Sekolah Menengah Atas (SMA) yang sesuai dengan kurikulum 2013 dan studi pustaka tentang penelitian yang relevan. Melakukan wawancara kepada guru-guru di sekolah untuk mengetahui informasi tentang buku ajar biodiversitas yang digunakan di sekolah, kondisi sekolah, dan karakteristik siswa.

\section{(2) Planning}

Merancang hasil kajian etnobiologi suku dayak Losarang yang akan dimasukkan ke dalam buku ajar biodiversitas, memetakan materi biodiversitas yang akan dibuat pada buku 
ajar, merancang desain buku ajarmengikuti panduan menurut NAAEE (2004) dengan enam karakteristik yang meliputi: fairness \& accuracy, depth, emphasis on skill building, action orientation, instructional soundness dan usability. Selain itu, penulisan buku ajar juga mengacu pada aspek penilaian buku teks BSNP. Merancang instrumen penelitian untuk menguji efektivitas buku ajar biodiversitas.

\section{(3) Develop Preliminary Form of Product}

Pengembangan produk yaitu buku ajar biodiversitas berbasis kajian etnobiologi Suku Dayak Losarang. Selain itu, dikembangkan instrumen penelitian dan instrumen validasi produk. Instrumen validasi berupa lembar penilain dengan skala likert (skor 1-4) serta kolom saran terhadap perbaikan buku ajar biodiversitas berbasis kajian Suku Dayak Losarang. Nilai hasil validasi dirata-rata untuk dikategorikan. Nilai 0 - 1,0 kategori tidak baik; 1,1 - 2,0 kurang baik; 2,1 -3,0 cukup baik; dan 3,1 - 4,0 baik (Arikunto, 2007).

Instrumen penelitian berupa soal postes untuk mengetahui efektivitas buku ajar serta angket untuk mengetahui respon siswa terhadap buku ajar tersebut.

\section{(4) Preliminary Field Testing}

Tahap validasi produk oleh pakar dalam hal ini validasi buku ajar biodiversitas berbasis kajian etnobiologi suku Dayak Losarang dilakukan oleh ahli dalam bidang media pembelajaran, bahasa,konten, dan beberapa praktisi guru. Proses validasi dilakukan bersama dalam acara Focus Group Discussion (FGD).

\section{(5) Main Product Revision}

Setelah dilakukan validasi ahli, produk direvisi sesuai dengan saran-saran melalui satu kali tahap bimbingan untuk perbaikan kualitas produk sebelum diujicobakan pada skala kecil. Revisi tersebut diselesaikan dengan ahli sebelum digunakan pada ujicoba skala kecil.

\section{(6) Main Field Testing}

Tahap uji coba skala kecil dengan menggunakan 24 siswa di SMA Negeri 1 Losarang, Indramayu. Uji coba skala kecil digunakan untuk menguji kelayakan dari buku ajar biodiversitas berbasis kajian etnobiologi Suku Dayak Losarang. Sebagai indikator buku ajar layak dilanjutkan pada uji coba skala luas adalah dengan menggunakan uji efektivitas. Disamping itu diberikan angket respon siswa terhadap buku ajar biodiversitas.

\section{(7) Operational Product Revision}

Tahap ini berisi revisi produk yang dikembangkan yaitu buku ajar biodiversitas berbasis kajian etnobiologi Suku Dayak Losarang.

\section{(8) Operational Field Testing}

Ujicoba skala besar dari buku ajar biodiversitas berbasis kajian etnobiologi Suku Dayak Losarang dilakukan pada tiga sekolah yang tersebar di Kabupaten Indramayu yaitu SMAN 1 Krangkeng, SMAN 2 Indramayu, dan SMAN 1 Losarang. Tujuan ujicoba skala besar adalah untuk mengukur efektivitas dari buku ajar biodiversitas berbasis kajian etnobiologi Suku Dayak Losarang dengan menggunakan uji beda (uji t). Respon siswa terhadap buku ajar juga dijaring melalui angket tertutup menggunakan skala likert. Hasil angket dipresentasikan untuk dimasukan dalam kategori sangat tinggi, tinggi, sedang, rendah, sangat rendah (Riduan, 2008).

\section{HASIL DAN PEMBAHASAN}

Hasil studi pendahuluan melalui wawancara guru mengenai buku biodiversitas yang biasa digunakan dalam pembelajaran ialah buku ajar yang diterbitkan oleh penerbit, bukan buatan 
guru. Guru sulit melepaskan ketergantungan terhadap penerbit buku dikarenakan kurangnya keterampilan menulis buku ajar (Achyani, et al., 2010). Hasil wawancara juga mengungkapkan bahwa pembelajaran biodiversitas disampaikan dengan metode observasi, diskusi bedah kasus, dan ceramah.

Analisis kurikulum juga dilakukan sebagai acuan dalam pembuatan buku ajar. Analisis konsep dalam kurikulum disesuaikan dengan kompetensi dasar. Adapun konsep biodiversitas meliputi:

a) Konsep keanekaragaman gen, jenis, dan ekosistem;

b) Biodiversitas Indonesia meliputi flora dan fauna yang dipisahkan garis wallace dan webber; c) Keunikan Hutan Hujan tropis;

d) Pemanfaatan biodiversitas;

e) Kerusakan/hilangnya biodiversitas;

f) Upaya pelestarian biodiversitas. Konsep-konsep tersebut disuguhkan dalam buku ajar biodiversitas yang dikaitkan dengan kajian etnobiologi Suku Dayak Losarang khususnya dan etnis-etnis lainnya di Indonesia sebagai tambahan.

Buku ajar biodiversitas berbasis kajian etnobiologi Suku Dayak Losarang yang telah dibuat selanjutnya divalidasi. Hasil validasi buku ajar oleh pakar dan praktisi dapat dilihat pada Tabel 1.

Tabel 1. Hasil Validasi Ahli dan Praktisi

\begin{tabular}{|c|c|c|c|c|}
\hline No & Aspek & Indikator & Rata-rata & Kategori \\
\hline 1 & $\begin{array}{l}\text { Kelayakan } \\
\text { Kebahasaan }\end{array}$ & $\begin{array}{l}\text { Lugas, komunikatif, dialog dan } \\
\text { interaktif, kesesuaian dengan } \\
\text { perkembangan peserta didik, } \\
\text { kesesuaian dengan kaidah bahasa }\end{array}$ & 3,60 & Baik \\
\hline 2 & $\begin{array}{l}\text { Kelayakan } \\
\text { Isi }\end{array}$ & $\begin{array}{l}\text { Kesesuaian } \text { materi } \\
\text { kompetensi dasar, keakuratan materi, } \\
\text { kemutakhiran materi, mendorong } \\
\text { keingintahuan }\end{array}$ & 3,46 & Baik \\
\hline 3 & $\begin{array}{l}\text { Kelayakan } \\
\text { Penyajian }\end{array}$ & $\begin{array}{l}\text { Teknik penyajian, pendukung } \\
\text { penyajian, penyajian pembelajaran, } \\
\text { koherensi dan kerunutan alur piker }\end{array}$ & 3,36 & Baik \\
\hline
\end{tabular}

Tabel 1 menunjukkan bahwa hasil validasi buku ajar biodiversitas berbasis kajian Suku Dayak Losarang berada pada kategori baik dari segi kelayakan bahasa, kelayakan isi, maupun kelayakan penyajian.

Pada aspek kelayakan kebahasaan, bahasa yang digunakan bersifat lugas, artinya kalimat yang dipilih sudah tepat dari segi ejaan dan tata bahasa, kalimat efektif serta menggunakan istilah-istilah baku. Menurut Afrahamiryani \& Ariani (2017), buku ajar bisa dikatakan valid dari kelayakan bahasa jika komunikatif, jelas, konsisten, dan sesuai dengan kaidah Bahasa Indonesia yang baik dan benar. Penggunaan bahasa yang baik dan benar akan mendorong kemampuan berbahasa yang baik di kalangan siswa secara lisan maupun tulisan (Reski, et al., 2016).

Buku tersebut juga komunikatif dalam menyampaikan informasi 
mengenai konsep kenekaragaman hayati dengan menyisipkan kearifan lokal Suku Dayak Losarang berdasarkan hasil kajian etnobiologinya. Kearifan lokal berisi gambaran tentang anggapan masyarakat yang bersangkutan tentang hal-hal yang berkaitan dengan struktur dan fungsi lingkungan, reaksi alam terhadap tindakan-tindakan manusia, dan hubungan-hubungan yang sebaiknya tercipta antara manusia dan lingkungan alamnya (Reski, et al., 2016). Pemahaman siswa terhadap ragam budaya dan kearifan lokal dapat meningkatkan nilai karakter siswa sebagai masyarakat akademis (Artha, et al., 2016).

Pada bagian pendahuluan buku terdapat pengantar mengenai biodiversitas Indonesia dan Suku Dayak Losarang, seperti sejarah, pendiri, dan filosofi hidup mereka. Bagian pendahuluan ini bertujuan memotivasi siswa dan menumbuhkan rasa ingin tahu siswa. Sebagaimana pendapat Tanjung \& Fahmi (2015) bahwa motivasi dapat dimunculkan dengan menggunakan bahan ajar yang tepat sehingga siswa mampu meningkatkan motivasi belajarnya. Pertanyaan-pertanyaan yang terdapat dalam bagian buku tersebut juga melatih siswa untuk berpikir kritis. Bahasa yang digunakan disesuaikan dengan perkembangan intelektual dan emosional peserta didik yaitu siswa tingkat SMA, tidak terlalu sederhana tetapi juga tidak berbelit-belit. Dalam Istiningrum, et al. (2016) menyatakan bahwa penulisan buku harus sesuai dengan bahasa yang mudah dipahami siswa.

Dari segi kelayakan isi buku, konsep keanekaragaman hayati yang disajikan sudah disesuaikan dengan materi yang ada pada kurikulum biologi dan tuntutan kompetensi dasar. Buku juga dilengkapi dengan gambar, contoh, data, diagram, dan ilustrasi kehidupan Suku Dayak Losarang yang dikaitkan dengan materi keanekaragaman hayati. Salah satu kriteria bahan ajar yang baik yaitu memuat materi ajar yang sesuai dengan kebutuhan dimana keluasan dan kedalaman materi mengacu pada tuntutan kurikulum (Achyani, et al., 2010).

Di dalam buku juga terdapat bedah kasus yang memuat permasalahan terkini mengenai kerusakan keanekaragaman hayati misalnya kasus pencemaran limbah pabrik keramik yang berada di satu kecamatan yang sama dengan Suku Dayak Losarang. Adanya kasus tersebut dapat mendorong siswa untuk mencari informasi lebih lanjut. Kasus yang disajikan dalam buku awalnya merupakan peristiwa nyata yang terjadi namun bukan dilingkungan sekitar Suku Dayak Losarang. Akan tetapi terdapat saran dari validator untuk perbaikan buku agar lebih baik lagi. Beberapa masukan diantaranya: 1) kasus kerusakan kenaekaragaman hayati yang ditampilkan sebaiknya berupa kasus nyata di sekitar wilayah Suku Dayak Losarang atau di kecamatan Losarang, 2) soal uji kompetensi baiknya merupakan soal-soal yang biasa muncul dalam Ujian Nasional, 3) penyajian manfaat keanekaragaman hayati (fauna) diperbanyak lagi, meskipun Suku Dayak Losarang tidak memanfaatkan fauna.

Aspek ketiga yaitu kelayakan panyajian juga berada pada kategori baik, namun memiliki nilai terendah. Hal tersebut karena pada saat buku ajar divalidasi belum terdapat glosarium, kunci jawaban soal latihan, dan daftar pustaka, seperti yang disajikan dalam hasil validasi dan gambar buku pada Gambar 1. Akan tetapi, untuk layout dan grafis sudah dinilai baik, termasuk sampul buku seperti yang terlihat pada Gambar 2. 


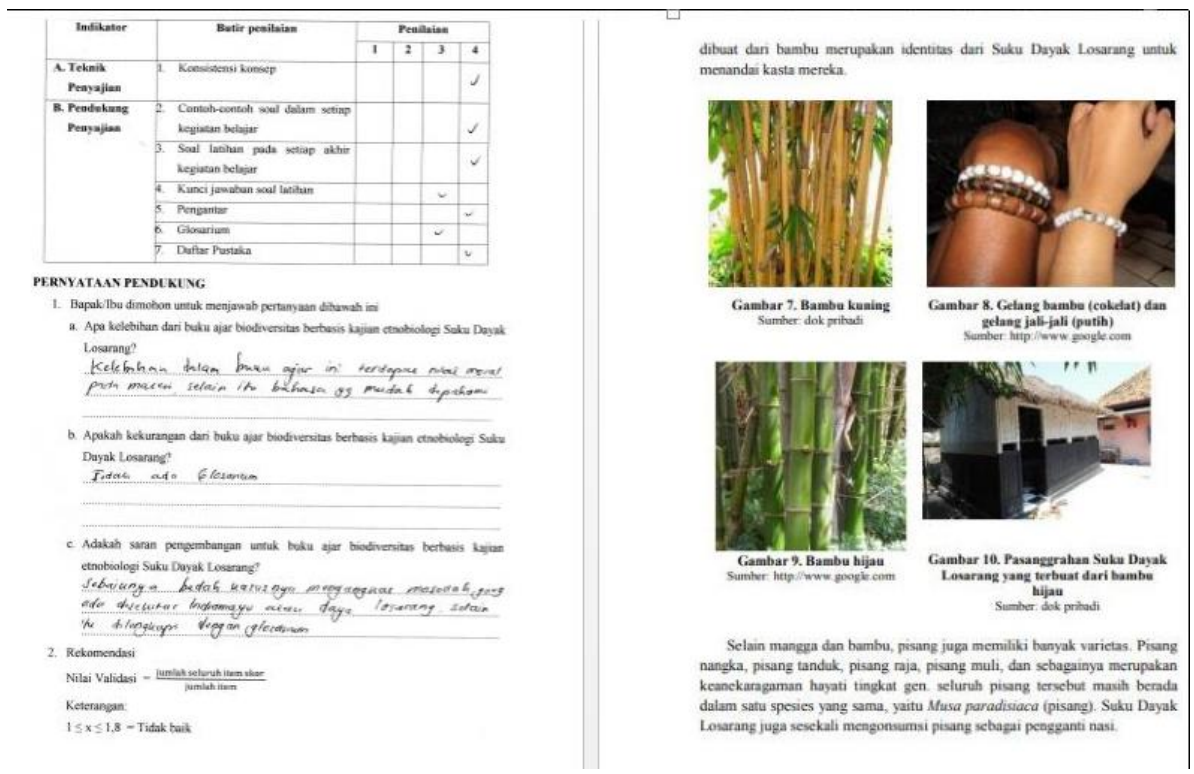

Gambar 1. Validasi kelayakan penyajian (kiri), contoh kelayakan penyajian pada buku (kanan)

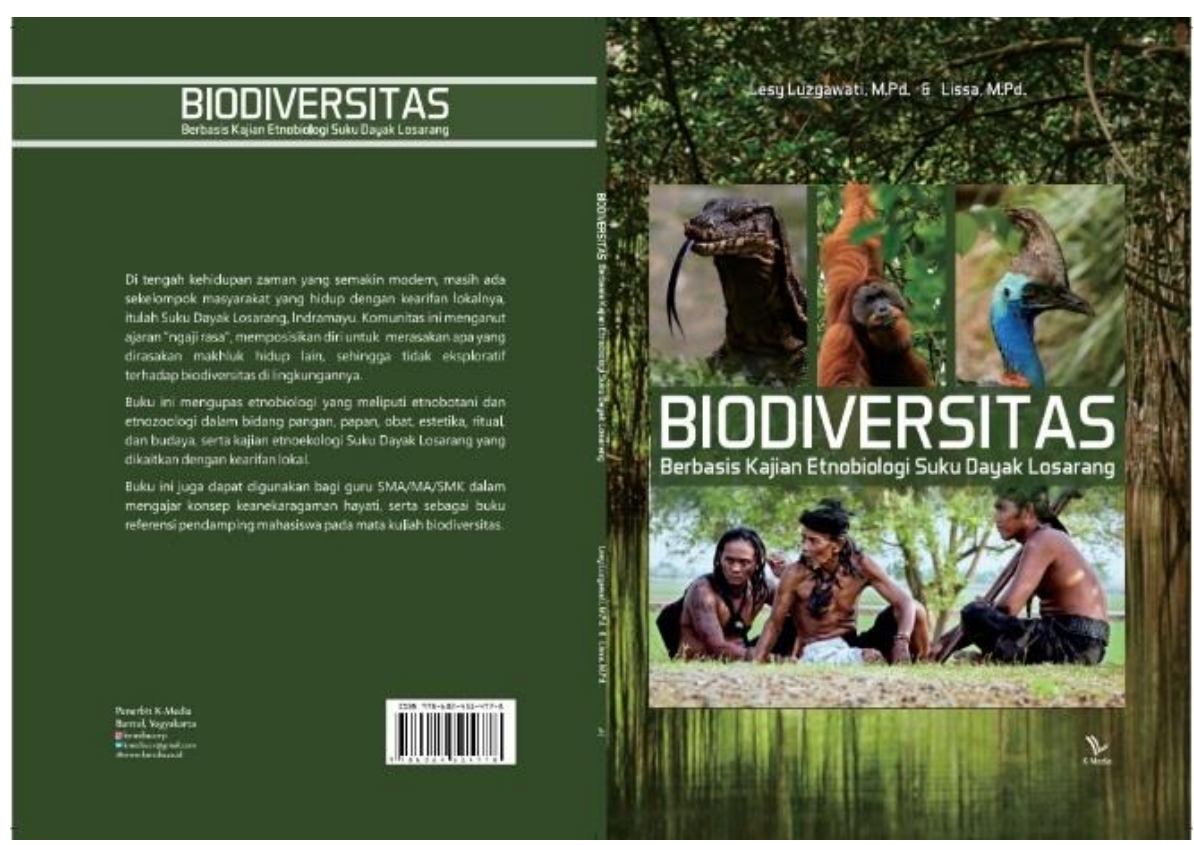

Gambar 2. Sampul buku biodiversitas berbasis kajian etnobiologi Suku Dayak Losarang

Indikator lainnya yaitu konsistensi konsep dan keutuhan makna mendapat nilai yang baik. Keutuhan makna dapat diperoleh karena penyajian yang sistematik. Sistematika penyajian materi menjadi aspek yang penting dalam penyusunan buku ajar, karena susunan materi yang runtut memudahkan siswa memahami materi secara keseluruhan (Prasetiyo \& Perwiraningtyas, 2017). Hal senada diungkapkan Wulandari (2017) bahwa materi yang disajikan secara runtut dari konsep dasar hingga konsep yang 
lebih rumit, dapat memudahkan siswa untuk memahami esensi materi.

Begitu pula dengan keterlibatan peserta didik, dimana ada bagian dari buku yang meminta siswa mengerjakan kegiatan mandiri agar dapat memahami konsep. Kegiatan mandiri berupa observasi di lingkungan sekitar sekolah untuk mengamati berbagai keanekaragaman hayati sehingga dapat membedakan keanekaragaman tingkat gen, jenis, dan ekosistem. Dengan demikian buku ajar dapat memfasilitasi siswa untuk belajar mandiri (Farida, 2017). Penggunaan buku ajar menekankan bagaimana siswa belajar dengan memanfaatkan lingkungan sekitar sebagai sumber belajar.

Hasil validasi buku ajar oleh pakar dan praktisi menunjukkan bahwa skor validasi pada ketiga aspek berada pada kategori baik sehingga buku ajar layak digunakan. Akan tetapi, sebelum digunakan buku ajar diperbaiki sesuai dengan saran validator terhadap buku ajar yang dikembangkan. Hasil produk pengembangan berupa buku ajar yang telah direvisi bertujuan untuk perbaikan buku ajar, sehingga pemakaian buku ajar menjadi lebih efisien, efektif dan komunikatif kepada pembaca, dengan tetap memperhatikan tujuan penyusunan buku ajar (Fidiastuti, 2016).

Buku telah melalui tahap validasi pada bagian kelayakan isi, kelayakan bahasa dan kelayakan penyajian dan telah dianggap valid oleh validator maka dilanjutkan adalah tahap uji coba skala kecil yang dilakukan di SMAN 1 Losarang selama tiga kali pertemuan. Uji coba skala kecil dilakukan untuk mengetahui efektivitas buku ajar yang ditinjau dari sudut siswa yaitu pada bagian hasil belajar yang sesuai dengan Kriteria Ketuntasan Mandiri (KKM) dan respon baik tentang penggunaan buku. Data tersebut diukur pada skala kecil dengan pertimbangan pengembangan yaitu, selain buku dinyatakan valid oleh tim validator juga penggunaannya tidak mengganggu hasil belajar siswa dengan indikator hasil belajar sesuai bahkan lebih dari KKM dan mendapat respon yang baik. Dasar pengembangan tersebut sejalan dengan (Hamidah, et al. 2017; Tinja, et al. 2017). Adapun data efektivitas buku ajar pada skala kecil terdapat pada Tabel 2.

Tabel 2. Hasil uji normalitas dan efektivitas pada skala kecil

\begin{tabular}{cccccccccc}
\hline Rata-rata & $\mathrm{N}$ & $\mathrm{Dk}$ & $\alpha$ & $\mathrm{X}^{2}$ hitung & $\mathrm{X}^{2}$ tabel & Ket & $\mathrm{t}_{\text {hitung }}$ & $\mathrm{t}_{\text {tabel }}$ & Keterangan \\
\hline 78,3 & 24 & 5 & 0,05 & 7,84 & 1,14 & Normal & 1,8 & 1,7 & Efektif \\
\hline
\end{tabular}

Hasil uji normalitas data pada skala kecil (Tabel 2) menunjukkan bahwa data berdistribusi normal sehingga uji efektivitas dilakukan dengan menggunakan uji t satu sampel. Hasil uji t satu sampel tersebut nampak bahwa buku ajar biodiversitas berbasis kajian Suku Dayak Losarang efektif digunakan dalam pembelajaran konsep keanekaragaman hayati di kelas X. Hal tersebut berarti hasil belajar siswa mencapai KKM sekolah.
Selain itu, hasil respon siswa secara keseluruhan indikator mendapat respon positif. Pembelajaran dengan menggunakan buku ajar biodiversitas berbasis kajian Suku Dayak Losarang mendorong siswa untuk berpartisipasi, membaca, dan mendengarkan, melihat, dan membangkitkan rasa ingin tahu siswa. Buku ajar yang didalamnya disajikan masalah atau kasus dapat mendorong aktivitas siswa dalam belajar 
(Nurmita, 2017). Pembelajaran dengan menggunakan buku ajar tersebut mendorong siswa mandiri, memotivasi siswa dalam belajar, memudahkan dalam mencari informasi, dan menumbuhkan pengalaman belajar yang bermakna. Adapun hasil respon siswa pada skala kecil dapat dilihat pada Tabel 4. Respon positif dari siswa berbanding lurus dengan hasil belajar yang mencapai KKM setelah menggunakan buku ajar biodiversitas berbasis kajian Suku Dayak Losarang. Hal tersebut menunjukan buku ajar efektif digunakan.
Kelayakan buku ajar dapat dilihat dari hasil analisis validitas, praktikalitas, dan efektivitas (Gitnia, et al., 2018). Hasil analisis uji skala kecil menunjukkan bahwa produk buku ajar telah memenuhi syarat yang diujicobakan, sehingga buku ajar diujicobakan kembali pada skala besar. Uji skala besar dilakukan di tiga sekolah yaitu SMA N 1 Losarang, SMAN 1 Krangkeng, dan SMAN 2 Indramayu. Hasil pengolahan data postes untuk melihat efektivitas buku ajar disajikan pada Tabel 3.

Tabel 3. Rata-rata hasil belajar, uji normalitas, dan uji efektivitas pada skala besar

\begin{tabular}{lcccccccc}
\hline \multicolumn{1}{c}{ Sekolah } & $\begin{array}{c}\text { Rata- } \\
\text { rata }\end{array}$ & $\mathrm{N}$ & $\mathrm{X}^{2}$ hitung & $\mathrm{X}_{\text {tabel }}^{2}$ & ket & $\mathrm{t}_{\text {hitung }}$ & $\mathrm{t}_{\text {tabel }}$ & Ket \\
\hline $\begin{array}{l}\text { SMA N 2 } \\
\text { Indramayu }\end{array}$ & 77,4 & 28 & 2,93 & 1,14 & Normal & 1,84 & 1,70 & Efektif \\
\hline $\begin{array}{l}\text { SMA N 1 } \\
\text { Krangkeng }\end{array}$ & 78,4 & 33 & 3,08 & 1,14 & Normal & 1,9 & 1,69 & Efektif \\
\hline $\begin{array}{l}\text { SMA N 1 } \\
\text { Losarang }\end{array}$ & 78,2 & 23 & 2,94 & 1,14 & Normal & 1,86 & 1,72 & Efektif \\
\hline
\end{tabular}

Hasil uji normalitas menunjukkan bahwa seluruh sampel di tiga sekolah berdistribusi normal. Uji efektivitas dengan menggunakan uji t satu sampel juga menunjukkan bahwa buku ajar biodiversitas efektif dalam pembelajaran biologi pada konsep keanekaragaman hayati di kelas X.
Pada uji skala besar juga dilakukan penyebaran angket untuk melihat respon siswa terhadap buku ajar biodiversitas. Hasil rata-rata persentase respon siswa juga hasilnya tidak jauh berbeda dengan respon siswa pada skala kecil. Semua indikator memiliki nilai besar dan berada pada kategori tinggi, seperti yang tertuang dalam Tabel 4.

Tabel 4. Respon siswa terhadap buku ajar keanekaragaman hayati berbasis kajian etnobiologi Suku Dayak Losarang

\begin{tabular}{|c|c|c|c|c|c|}
\hline \multirow[t]{2}{*}{ No } & \multirow[t]{2}{*}{ Indikator } & \multicolumn{2}{|c|}{ Skala kecil } & \multicolumn{2}{|c|}{ Skala besar } \\
\hline & & Nilai (\%) & Kategori & Nilai (\%) & Kategori \\
\hline 1. & $\begin{array}{l}\text { Keinginan untuk bertindak } \\
\text { atau berpartisipasi }\end{array}$ & 85 & Tinggi & 84,6 & Tinggi \\
\hline 2. & $\begin{array}{l}\text { Membaca dan } \\
\text { mendengarkan }\end{array}$ & 87,5 & Tinggi & 84,5 & Tinggi \\
\hline 3. & Melihat & 80 & Tinggi & 82,4 & Tinggi \\
\hline
\end{tabular}




\begin{tabular}{clcccc}
\hline 4. & $\begin{array}{l}\text { Menimbulkan atau } \\
\text { membangkitkan perasaan }\end{array}$ & 88,3 & Tinggi & 85,7 & Tinggi \\
\hline 5. & Mengamati & 77,5 & Tinggi & 80,9 & Tinggi \\
\hline 6. & Memotivasi dalam belajar & 89,2 & Tinggi & 77,1 & Tinggi \\
\hline 7. & Bersifat fleksibel & 82,5 & Tinggi & 78,6 & Tinggi \\
\hline 8. & $\begin{array}{l}\text { Memudahkan siswa untuk } \\
\text { memperoleh informasi }\end{array}$ & 85,8 & Tinggi & 77,3 & Tinggi \\
\hline 9. & $\begin{array}{l}\text { Menumbuhkan } \\
\text { pengalaman belajar siswa }\end{array}$ & 85,8 & Tinggi & 85,9 & Tinggi \\
\hline 10. & Self Contained (mandiri) & 80 & Tinggi & 79,6 & Tinggi \\
\hline
\end{tabular}

Hasil uji coba skala luas menunjukan bahwa buku ajar efektif digunakan pada tiga sekolah dengan asumsi ketiga sekolah tersebut merupakan perwakilan dari bagian daerah di Indramayu yaitu Indramayu Barat dengan SMAN 1 Losarang, Indramayu kota dengan SMAN 2 Indramayu dan Indramayu timur dengan SMAN 1 Krangkeng. Sehingga dapat disimpulkan bahwa buku ajar efektif digunakan di Kabupaten Indramayu.

Pada umumnya buku ajar hanya memuat uraian bahan tentang mata pelajaran atau bidang studi tertentu. Adanya pengembangan buku ajar biodiversitas berbasis kajian etnobiologi Suku Dayak Losarang dapat membantu siswa memahami materi keanekaragaman hayati. Melalui buku ajar, materi yang disajikan bersifat sistematis dan menggunakan bahasa komunikatif, lugas, sehingga mudah dipahami oleh peserta didik (Suwarni, 2015).

\section{SIMPULAN DAN SARAN}

Hasil validasi pakar dan praktisi memperlihatkan kelayakan isi, bahasa, dan penyajian berada pada kategori baik. Sebaiknya jika melakukan pengembangan buku ajar kembali, kelayakan grafik juga dinilai dengan memuat berbagai indikator kelayakan grafik. Hasil uji t satu sampel pada skala kecil dan skala besar memperlihatkan hasil bahwa buku ajar tersebut efektif dalam pembelajaran. Respon siswa juga sangat positif terhadap buku ajar terbukti dari persentase nilai yang berada pada kategori tinggi. Berdasarkan hasil validasi dan uji efektivitas maka, dapat disimpulkan bahwa buku ajar biodiversitas berbasis kajian etnobiologi Suku Dayak Losarang layak digunakan di SMA Kelas X di wilayah Kabupaten Indramayu.

\section{DAFTAR PUSTAKA}

Achyani, et al. (2010). Model Penulisan Buku Ajar Biologi SMA Berwawasan Ekologi dan Lokal untuk Meningkatkan Kepedulian Siswa terhadap lingkungan. Bioedukasi, 1(1), 1-8

Afrahamiryani \& Ariani, D. (2017). Analisis Validitas Buku Ajar untuk Sistem Perkuliahan Elearning pada Mata Kuliah Kimia Dasar di FKIP UMMY Solok.Jurnal Eksakta Pendidikan, 1(2), 104-111

Arikunto, S. (2007). Prosedur penelitian suatu pendekatan praktik. Jakarta, Indonesia: Rineka Cipta.

Artha, Y. G., Saptasari, M., \& Mahanal, S. (2016). Pengembangan Buku Ajar Etnobotani melalui Studi 
Etnobotani Kawasan Masyarakat Lokal Desa Trunyan. Jurnal Pendidikan: Teori, Penelitian, dan Pengembangan, 1(4), 603-607.

Bahri, S., Syamsuri, I., \& Mahanal, S. (2016). Pengembangan Modul Keanekaragaman Hayati dan Virus Berbasis Model Inkuiri Terbimbing untuk Siswa Kelas X Man 1 Malang. Jurnal Pendidikan: Teori, Penelitian, dan Pengembangan,1(2), 127-136.

Borg, M. D., \& Gall, J. P. (2003). Educational Research an Introduction. Boston: Pearson Education Inc.

Farida, E. Y. (2017) Pengembangan Buku Ajar Bahasa Indonesia Sebagai Penunjang Perkuliahan FTIK UNISNU Jepara. Jurnal Pendidikan dan Profesi Pendidik,3(1), 28-35

Fidiastuti, H. R. \& Rozana, K. M. (2016). Developing Modul Of Microbiology Subject Through Biodegradation By Using The Potencial Of Indigen Bacteria. Jurnal Pendidikan Biologi Indonesia, 2(2), 125-132

Firdaus, D. W. (2017). Pewarisan Nilainilai Historis dan Kearifan Lokal Masyarakat Kampung Adat dalam Pembelajaran Sejarah. Jurnal artefak, 4(2), 129-134

Gitnia, S., Kamus, Z., \& Gusnedi. (2018). Analisis Validitas, Praktikalitas, dan Efektivitas Pengembangan Bahan Ajar Terintegrasi Konten Kecerdasan Spiritual Pada Materi Fisika Tentang Vektor dan Gerak
Lurus. Pillar of Physics Education. 11(2), 153-160.

Hamidah, I., Indriyanti, D.R., Nugrahaningsih. W. H. (2017). Pengembangan Bahan Ajar Sub bab antioksidan Berbasis Kajian Pola Konsumsi Masyarakat Pesisir Indramayu. Journal of Innovative Science Education. 6 (1), 59-65

Istiningrum, R., Amin, M., \& Lestari, U. (2016). Pengembangan Buku Ajar Biologi Sel Berbasis Bioinformatika. Jurnal Pendidikan: Teori, penelitian, dan Pengembangan. 1(9), 1693-1699

Leksono, M.S., Syachrurozi A., \& Marianingsih, Pipit. (2015). Pengembangan Bahan Ajar Biologi Konservasi Berbasis Etnopedagogi. Jurnal Kependidikan volume. 45(2), 168-183

Luzyawati, L. \& Lissa, L. (2019) Ethnobiology Eksplorationof Suku Dayak Losarang, Indramayu District-West Java Province. Bioscience, 3(2), 144-154.

Mardiansyah, N., Tindagen, M., \& Rambitan, V. M. M. (2017). Analisis Permasalahan Bahan Ajar Berbasis Biodiversitas Daerah Kalimantan Timur Pada Pembelajaran Ipa Biologi SMP Di Kota Samarinda. Jurnal Pendidikan: Teori, Penelitian, dan Pengembangan.2(11), 1475-1481

Mulyasa. (2013). Pengembangan dan Implementasi Kurikulum 2013. Bandung: Remaja Rosdakarya 
Nurmita, F. (2017). Pengembangan Buku Ajar Siswa dan Buku Guru Berbasis Matematika Realistik untuk Meningkatkan Pengetahuan, Sikap, dan Keterampilan Matematika Siswa Kelas VII SMP Al Karim Kota Bengkulu. EDU-MAT Jurnal Pendidikan Matematika, 5(1), 8698

Prasetiyo, N. A, Perwiraningtyas, P. (2017). Pengembangan Buku Ajar Berbasis Lingkungan Hidup Pada Matakuliah Biologi Di Universitas Tribhuwana Tunggadewi. Jurnal Pendidikan Biologi Indonesia. 3(1), 19-27

Reski, Harida, Masriani. (2016). Pengembangan Suplemen Buku Ajar Berbasis Kearifan Lokal Pada Materi Biosintesis Eikosanoid. Jurnal Pendidikan dan Pembelajaran Khatulistiwa, 5(11), 1-13.

Riduan. (2008). Metode dan Teknik Menyusun Tesis. Bandung: Alfabeta.

Suwarni, E. (2015). Pengembangan Buku Ajar Berbasis Lokal Materi Keanekaragaman Laba-Laba di
Kota Metro sebagai Sumber Belajar Alternatif Biologi untuk Siswa SMA Kelas X. Bioedukasi Jurnal Pendidikan Biologi, 6(2), 86-92.

Tanjung \& Fahmi. (2015). Urgensi Pengembangan Bahan Ajar Geografi Berbasis Kearifan Lokal. Jurnal Pendididkan Geografi, 20(1), 24-29

Tinja. Y., Towaf. S.M., Hariyono. (2017). Pengembangan Bahan Ajar Tematik Berbasis Kearifan Lokal Sebagai Upaya Melestarikan Nilai Budaya Pada Siswa Sekolah Dasar. Jurnal Pendidikan, 2(9), 1257-1261

Utami, U. P. (2017). Pengembangan Buku Ilmiah Populer Keanekaragaman Mangrove Berbasis Pembelajaran Kontekstual pada Materi Keanekaragaman Hayati di SMA. Tesis: Universitas Jambi

Wulandari, Widyaningrum, P., \& Setiati, N. (2017). Pengembangan Suplemen Bahan Ajar Biologi Berbasis Riset Identifikasi Bakteri untuk Siswa SMA. Journal of Innovative Science Education, 6(2), 155-161 